\title{
The Impact of Capital Account Liberalization on China's Short-Term International Capital Flows
}

\author{
LijunYu \\ School of Economics and Management, Beijing Jiaotong University, Beijing, China \\ 14120496@bjtu.edu.cn
}

\begin{abstract}
Keywords: Capital account liberalization; Short-term international capital flow (SCF) ; Impulse response; Variance decomposition

Abstract:Capital account liberalization promotes the free flow of capital in the global scope, so the resources can be effectively configured. However, the frequent movement of the short-term international capital brought by this kind of opening, also led to the outbreak of financial crisis. Therefore, the thesis aims to analyze the effect of capital account opening on short-term international capital flows. The results show that capital account liberalization has great influence on the direction and scale of the short-term international capital flows.
\end{abstract}

\section{Introduction}

At present, China's capital account is not fully open.To some extent, the control of capital account restricts and mitigates the impact of short-term international capital flows on China's economy. In the future, capital account liberalization is an inevitable trend. As one of the most potential economies, China is bound to become the main profitable place for short-term international capital. The impact of short-term international capital flows on China's economy may be a boost or an attack. So it is worth to do research on how capital account liberalization affectsshort-term international capital flows.

\section{Literature Review}

There are many detailed studies about the impact of capital account liberalization on short-term international capital flows. Chen Yulu(2004) usedthree methodsto calculate the opening degree of capital account in ten Asian countries, they found thatthe possibility of arbitragebetween the high opening degree countries and the reference countries is low. Liu Yi (2012) found that the increase of the capital account openness will raise the volatility of the price level as well as affect the interest policies to control price level. Meanwhile, when the degree is higher than a certain value, along with the more openness,the actual asset price and interest rate may change in same pace. Yang Zihui, Chen Chuanglian (2015) found that in the process of gradual opening of capital accounts ,thenational and international investment return is gradually converging. When a country with lowfinancial development degree, the opening of the capital account will reduce the investment of security and foreign direct investment.

\section{Empirical Research}

3.1 Scale calculation of short-term international capitalflow. The methods of measurement can be divided into three categories: the direct method (Cuddington, 1986), the indirect method (World Bank, 1985) and mixed method (Dooley, 1986) . The results are shown in Fig. 1. 


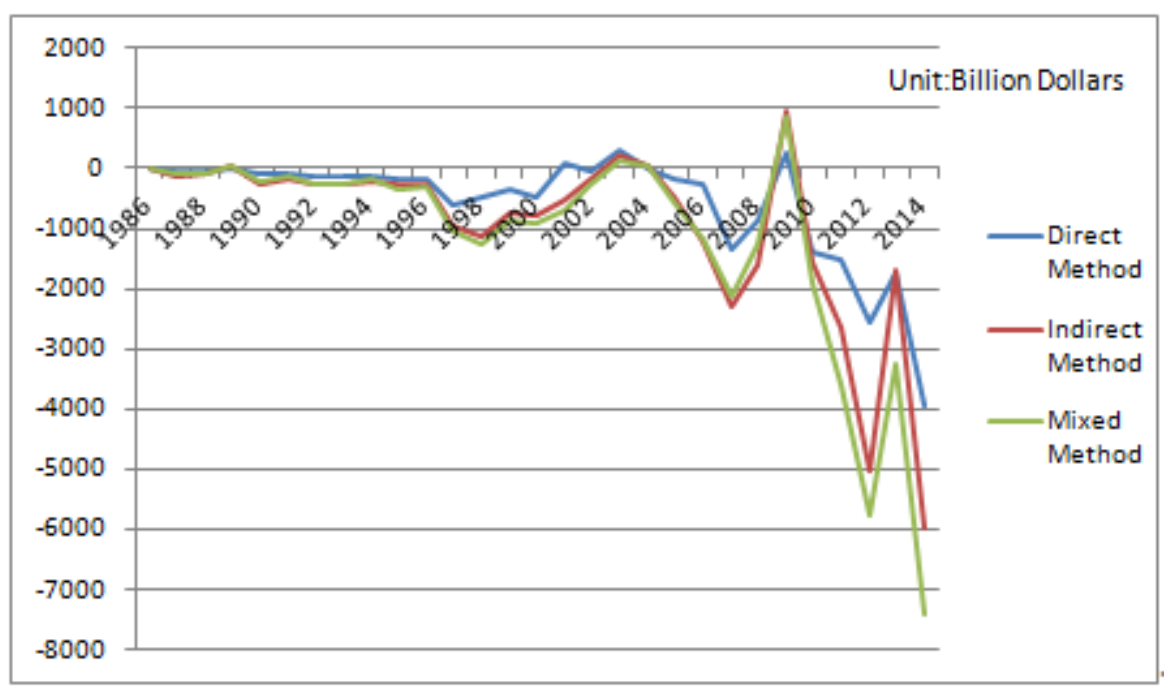

Fig. 1 The scale of China's short-term international capital flows

By comparison, it can be seen that the volatility of SCF which was measured by the mixed method is the largest in the three measure methods, and the second is the indirect method. The three methods can not accurately calculate the scale of short-term international capital flows, but they can roughly measure the trend of short-term international capital flows.

3.2 Index selection of capital account liberalization. There are many researches about calculating the opening degree of capital account in the world. The main calculation methods can be divided into two categories, which are constraint calculation and open calculation. This paper selects open calculation method to measure the degree of capital account in China. According to the situation of our country, the following indexes are selected.

$$
\begin{aligned}
& \text { CI = Capital inflows/ GDP } \\
& \text { CO = Capital outflows / GDP } \\
& \text { DI = Direct investment / GDP } \\
& \text { PI= Securities investment / GDP } \\
& \text { OI= Other investment / GDP }
\end{aligned}
$$

\subsection{Methology}
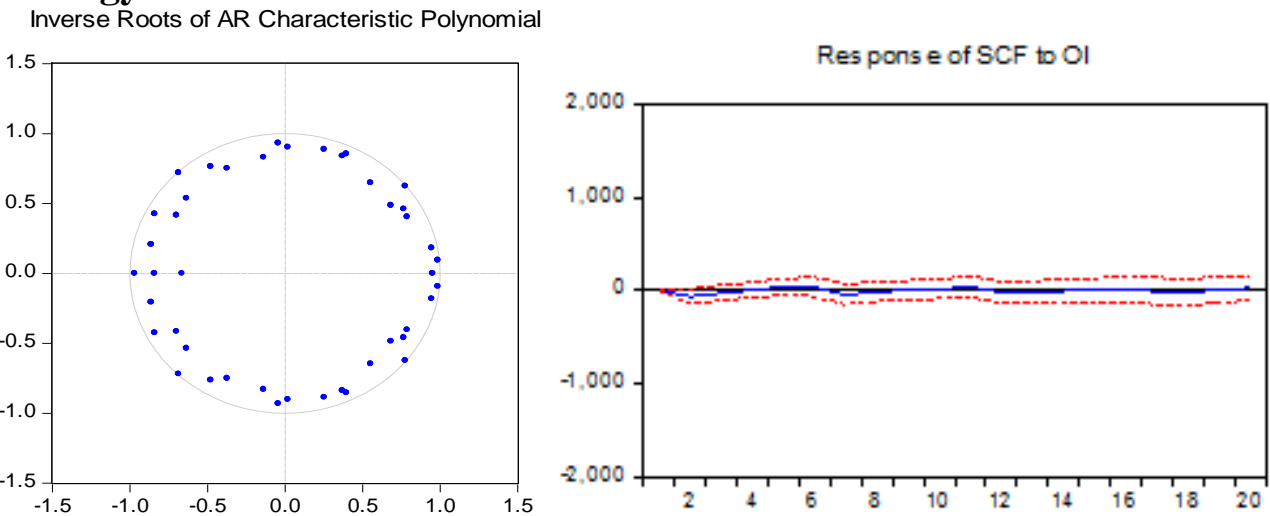

Fig. 2 Characteristic root graph of VAR test Fig. 3 Impulse response of SCF to capital account

The article uses the quarterly data from 2000 to 2014as the research object. In the empirical test, we selected indicators includinginterest margin between U.S. and China,RMB exchange rate and opening level of capital account. Firstly, I established the VAR model to test the stability of time series. The results show that the time series is stationary ( see Fig. 2). Then, it is reasonable to do impulse response and variance decomposition analysis. The results of impulse response analysis can beseen in Fig. 3 and Fig. 4. 

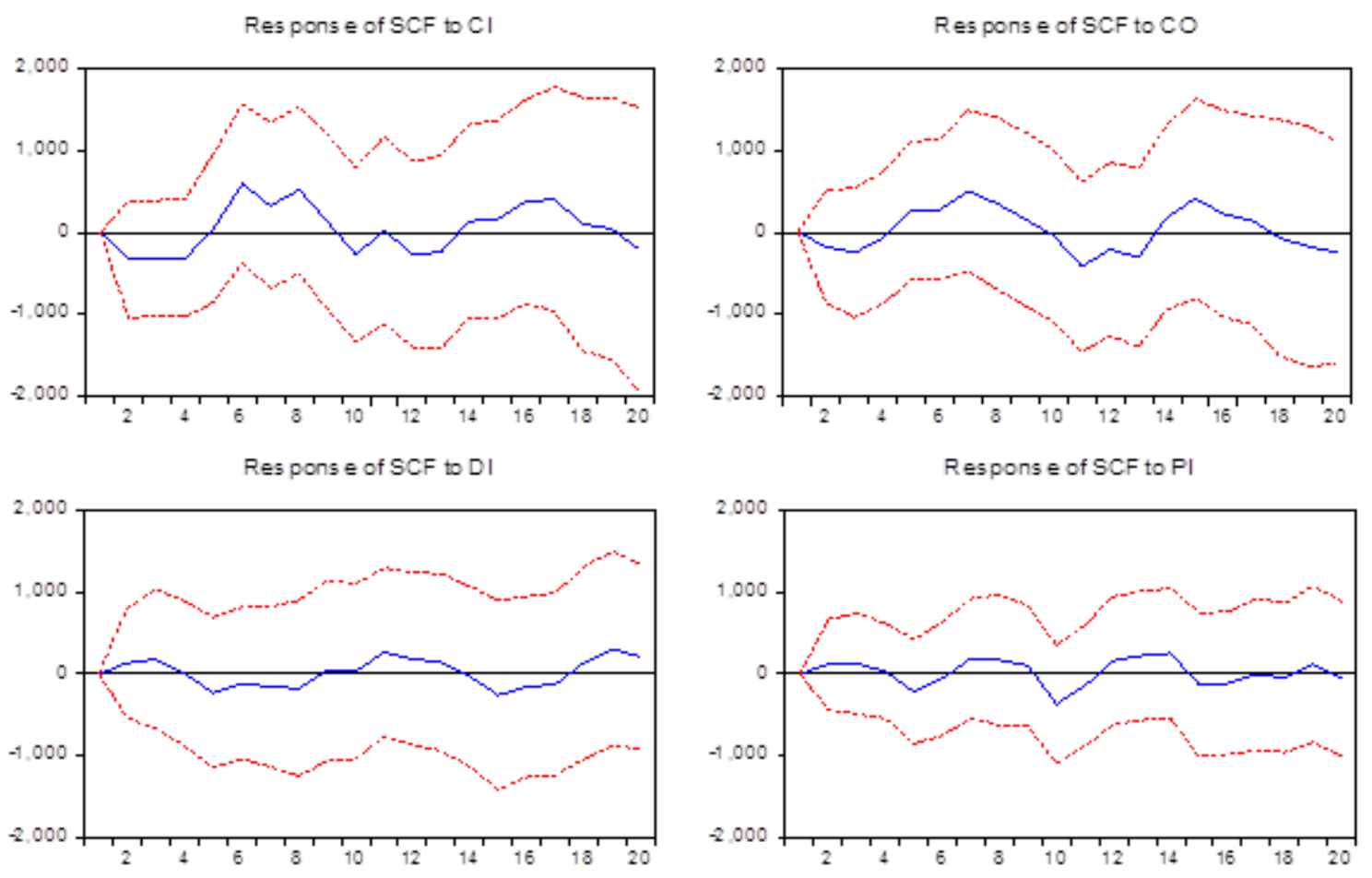

Fig. 4 Impulse response of SCF to capital accounts

The results of impulse response analysis show that increasing openness of capital inflows and outflows will lead to a small outflow of short-term international capital from the first to the forth period, and the short-term international capital will flow in China from the fifth period. By observing changes in the twenty periods, the overall performance is capital inflows, but the short-term international capital flows will experience greater volatility. This is because Chinese policy of " Easy in And Strict out " makes international investors worry about the smooth outflows after capital gains. So reducing the control of capital outflows will attract capital inflows. The results show that improving the degree of openness of direct investment will initially lead to short-term international capital inflows. The short-term international capital will begin to outflow from the forth period and will last until the ninth period. Improving the degree of openness of securities investment channels will also lead to the short-term international capital inflows, and only in the fifth phase there is a brief capital outflows. Improving the openness of capital projects which flow through other investment channels has little effect on short-term international capital flows.

The variance decomposition can analyze the contribution of each variable to the change. The results are shown in Table 1 . From the results of variance decomposition, we can see that the changes of the short-term international capital flows in China are mainly affected by their own, the explanatory power is above $50 \%$ in the first five periods, and the influence degree is gradually decreasing. When the direction of short-term international capital flows changes, because of asymmetric information, the international investors usually expect and choose in the same way.

Table 1 Variance decomposition results

\begin{tabular}{|l|l|l|l|l|l|l|l|}
\hline Period & SCF & CI & CO & DI & PI & OI & Others \\
\hline 1 & 100.00 & 0.00 & 0.00 & 0.00 & 0.00 & 0.00 & 0 \\
\hline 2 & 80.53 & 2.59 & 0.73 & 0.43 & 0.31 & 0.09 & 15.32 \\
\hline 3 & 73.19 & 4.20 & 1.85 & 1.00 & 0.56 & 0.09 & 19.12 \\
\hline 4 & 62.09 & 5.24 & 1.64 & 0.85 & 0.49 & 0.07 & 29.61 \\
\hline 5 & 53.61 & 4.45 & 2.42 & 1.46 & 1.09 & 0.08 & 36.87 \\
\hline 6 & 46.75 & 7.96 & 2.96 & 1.39 & 0.96 & 0.09 & 39.91 \\
\hline 7 & 41.53 & 8.08 & 5.26 & 1.48 & 1.20 & 0.10 & 42.34 \\
\hline 8 & 39.23 & 10.07 & 6.06 & 1.67 & 1.39 & 0.09 & 41.5 \\
\hline 9 & 38.21 & 9.84 & 6.07 & 1.62 & 1.43 & 0.09 & 42.74 \\
\hline 10 & 36.85 & 9.87 & 5.71 & 1.53 & 2.53 & 0.08 & 43.44 \\
\hline
\end{tabular}


Short-term international capital flows are largely influenced by capital account openness, while there is a certain lag effect. The most obvious influence is the opening degree of international capital inflows, the initial explanation is $2.59 \%$, and then the contribution enhances more and more, the explaining extent can reach upto $10 \%$ in the final three periods. Secondly, the openness of the capital outflow can contributeabout $6 \%$ of the influence. The opening degree of direct investment and securities investment can explain parts of the short-term international capital flows, but the explanatory power is small and the lag effect is obvious. The explanation power of other investment projects is the smallest.

\section{Conclusions}

The empirical parts focuse on the impact of capital account openness (CI, CO, DI, PI, OI) on the short-term international capital flow (SCF). From the empirical results, we find that the short-term international capital flows in our country are mainly affected by their own, and its changes have a positive impact on their own. Improving the openness of capital account will significantly fluctuate the direction and scale of China's short-term international capital flows.

In the circumstance of undeveloped capital market and financial system in China, the Chinese government should follow the proper order, accelerate the establishment of a macro-prudential regulatory framework and give great impetus to domestic structural reform as well as establishing crisis warning, management and coping mechanisms.

\section{Reference}

[1] Chen Yulu, Zhou Qing. Analysis on the openness and the actual spread of capital projects. Financial Research (2004).

[2] Liu Yi, Pan Zaijian. Research on the impact of capital projects on the price level and asset prices. Shanghai Finance (2012).

[3] Yang Zihui, Chen Chuanglian. Research on cross-border capital flow under the condition of financial deepening. Financial Research (2015).

[4] Weng Dongling. International capital flows and the opening of China's capital account.Beijing: China Economic Press, 2010. 